\title{
'Rice bodies in the knee': classic tuberculosis of the knee
}

\author{
Santosh Somayya Jeevannavar, Prasanna Baindoor
}

Department of Orthopaedics, SDM College of Medical Sciences and Hospital, Dharwad, Karnataka, India

\section{Correspondence to}

Dr Santosh Somayya Jeevannavar, drssj99@gmail.com

Accepted 21 March 2014
CrossMark

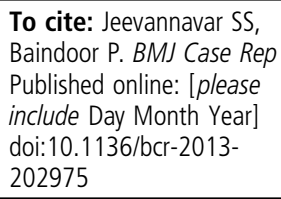

\section{DESCRIPTION}

A 32-year-old man presented with left knee pain and swelling of 8 months duration. The pain was insidious in onset and associated with swelling of the left knee. History was unremarkable; there were no major diseases or surgery. There was no history of fever or injury to the knee. Initially the patient consulted a local doctor and was treated with analgesics. However the pain and swelling persisted for which he was referred to our hospital. Clinical examination of the left knee revealed swelling which was parapatellar and on palpation was suggestive of synovial thickening and hypertrophy. Knee movements were full but terminally painful. Provocative tests to evaluate meniscus and ligaments were normal. Radiographs of the left knee joint (figure 1) revealed patchy periarticular osteoporosis with wellmaintained joint space. Blood investigations revealed an elevated erythrocyte sedimentation rate of $58 \mathrm{~mm}$ and $\mathrm{C}$ reactive protein was positive (1:32). MRI scan of the left knee revealed synovial thickening and hypertrophy with effusion in suprapatellar bursa. Erosion with marrow oedema adjoining the periarticular surfaces of femur and tibia with multiple loose bodies in the joint cavity. The cruciate and collateral ligaments were normal (figures $2 \mathrm{~A}$ and $\mathrm{B}$ ). MRI scan was suggestive of chronic infective pathology and a tissue biopsy was advised. The patient underwent a synovial biopsy with subtotal synovectomy through medial parapatellar approach. On arthrotomy the synovial tissue was found to be inflamed and hypertrophied, with multiple rice bodies (figure 3) along with unhealthy granulation tissue. Articular cartilage was normal with some periarticular erosions. The histopathology report revealed many caseating granulomas consisting of epithelioid cells and Langerhan's giant cells suggestive of tuberculosis. PCR test for $M$ tuberculosis DNA was positive.

The patient was started on category I antitubercular chemotherapy according to RNTCP (Revised National Tuberculosis Control Program) (H-isoniazid (300 mg), R-rifampicin (450 mg), Z-pyrazinamide, E-ethambutol $(1200 \mathrm{mg})$ ) which includes a 2-month intensive phase and 4-month continuation phase of four drugs at thrice-weekly schedule for the 2-month intensive phase and two drugs at thrice-weekly schedule for the remaining 4 months of continuation phase.

Gradual mobilisation of the left knee was done. At 1 year follow-up the patient had relief from pain and swelling with knee movements from 0 to $100^{\circ}$.

Rice bodies occurring in joints affected by tuberculosis were first described in 1895 by Reise. ${ }^{1}$

Rice bodies mainly consist of fibrin and are commonly seen in relation to joints, bursa or tendon sheaths in patients with rheumatoid arthritis, tubercular arthritis or tenosynovitis. ${ }^{23}$ Although rice bodies in relation to tubercular tenosynovitis of hand and other rheumatological and non-rheumatological conditions have been reported extensively, their existence in relation to tuberculosis of the knee is underreported. ${ }^{4}$ They are thought to arise from microinfarction after intra-articular synovial inflammation and ischaemia after which they are shed into the articular or bursal fluid. ${ }^{5}{ }^{6}$ Popert $e t a l^{7}$ proposed a de novo formation of rice bodies in synovial fluid independent of synovial tissue. In our patient the

Figure 1 X-ray of the left knee showing per articular osteoporosis with mild reduction in joint space. 
Figures 2 (A and B) MRI of the left knee showing synovial effusion, hypertrophy with loose bodies in the knee joint cavity.

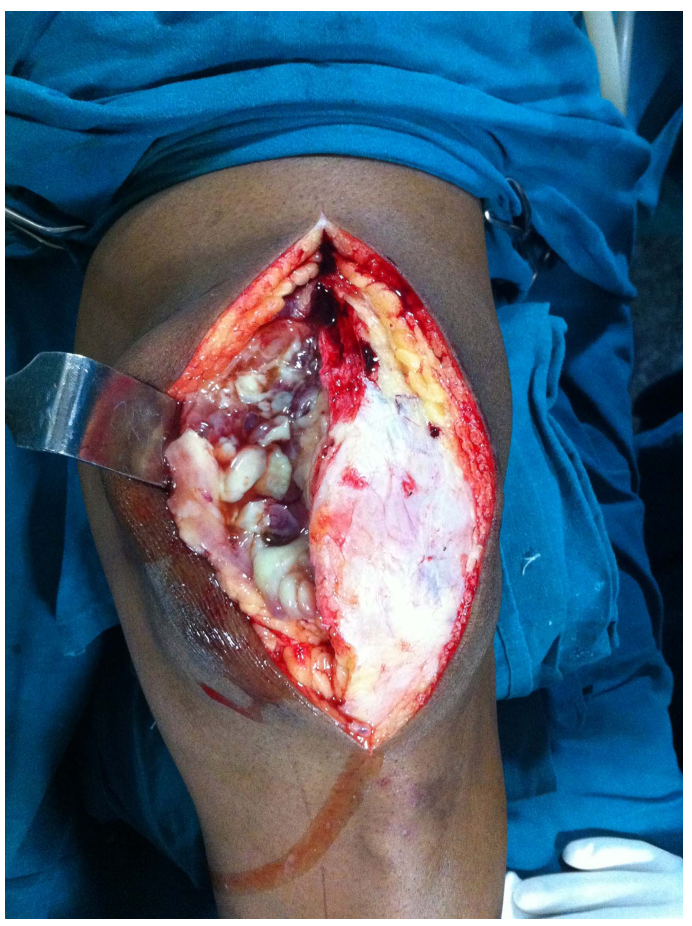

Figure 3 Intraoperative photograph after arthrotomy, showing rice bodies with unhealthy granulation tissue.

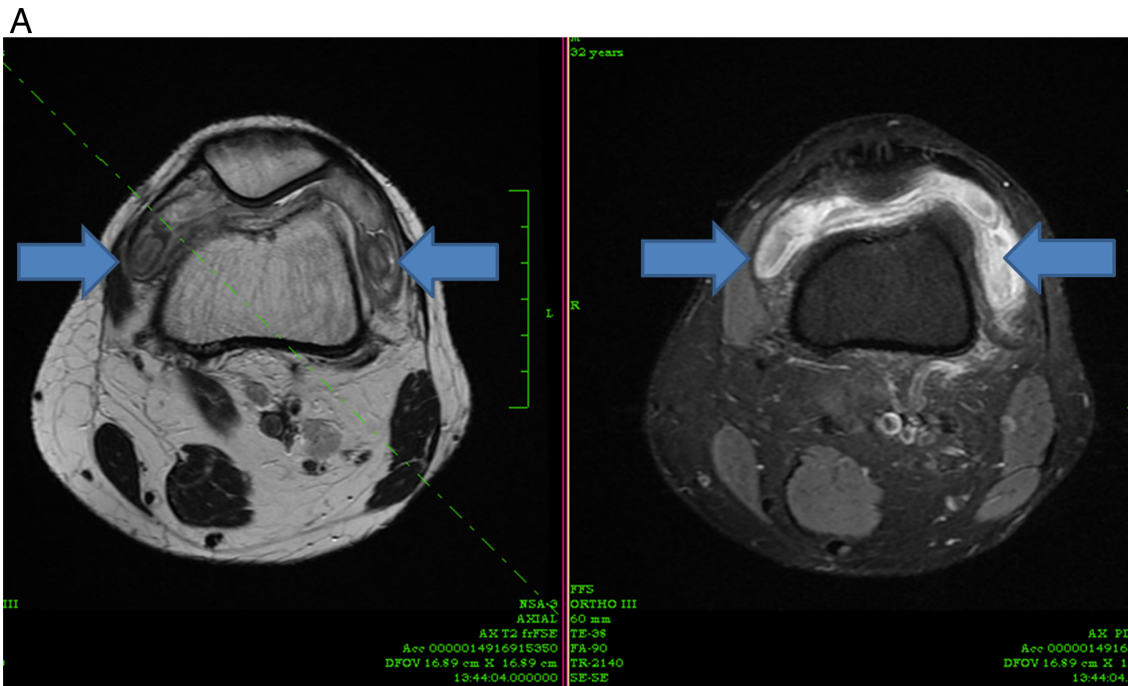

B

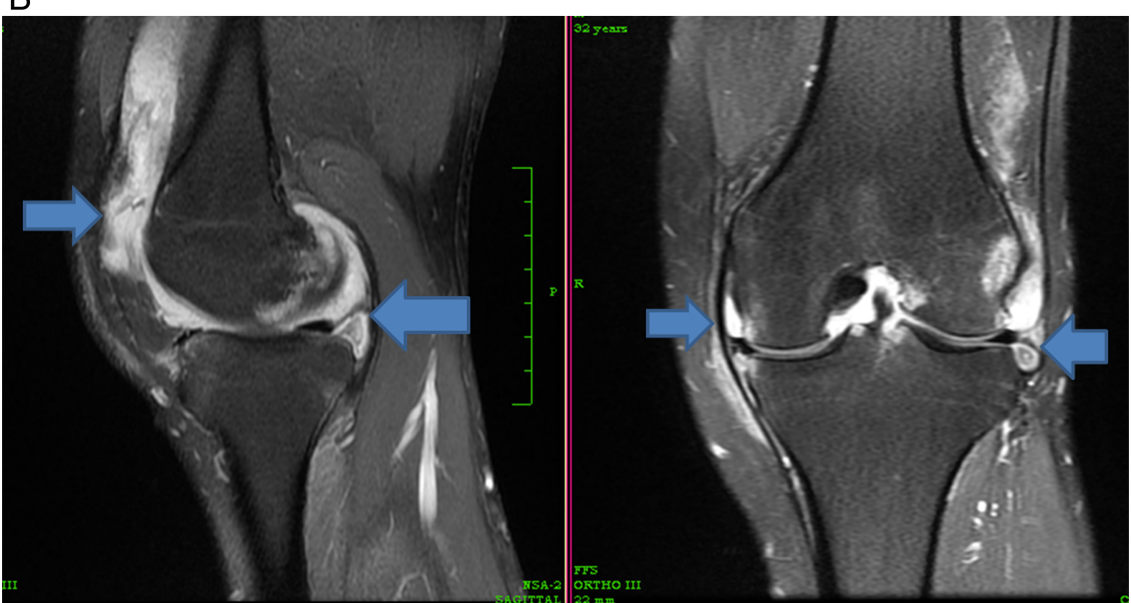

clinical presentation was not specific for either tuberculosis or any rheumatological condition. The presence of rice bodies in relation to joint cavity, bursa or tendon sheaths during surgery points towards a diagnosis of tuberculosis or any rheumatological condition. Rice bodies regardless of any cause should be removed as presence of fibrin, which is a known irritant of synovial tissue, will act as a stimulant for continuous synovial inflammation. ${ }^{8}$ Our patient was further investigated for any other rheumatological condition and was found negative. In conclusion, rice bodies found during surgery are highly indicative of tuberculosis or rheumatological conditions, and they should be removed as their presence will act as a persistent stimulant for synovial proliferation.

\section{Learning points}

- Rice bodies are mainly formed of fibrin and are seen in relation to joints, bursa or tendon sheaths in patients with rheumatoid arthritis, tuberculosis or tenosynovitis.

- Although rice bodies in relation to tuberculosis of large joints like knee are rarely reported, our case demonstrates that they can be seen even in large joints.

- Total synovectomy along with complete clearance of rice bodies, combined with chemotherapy is curative. 
Contributors SSJ and PB were involved in the diagnosis and treatment of the patient.

Competing interests None.

Patient consent Obtained.

Provenance and peer review Not commissioned; externally peer reviewed.

\section{REFERENCES}

1 Suso S, Piedro L, Ramon R. Tuberculous synovitis with 'rice bodies' presenting as carpal tunnel syndrome. J Hand Surg [Am] 1988;13:574-6.

2 Berg E, Wainwright R, Barton B, et al. On the nature of rheumatoid rice bodies: an immunological, histochemical, and electron microscope study. Arthritis Rheum 1977:20:1343-9.
3 Pimm LH, Waugh W. Tuberculous tenosynovitis. J Bone Joint Surg 1957;39B:91-101.

4 Assik M, Eralp L, Cetik O, et al. Rice bodies of synovial origin in the knee joint. Arthroscopy5 2001;17:E19 1.

5 Chen A, Wong LY, Sheu CY, et al. Distinguishing multiple rice body formation in chronic subacrominal-subdeltoid bursitis from synovial chondromatosis. Skeletal Radiol 2002;31:119-21.

6 Steinfeld R, Rock MG, Younge DA, et al. Massive subacromial bursitis with rice bodies. Clin Orthop 1994;30:185-90.

7 Popert AJ, Scott DL, Wainwright AC, et al. Frequency of occurrence, mode of development, and significance of rice bodies in rheumatoid joints. Ann Rheum Dis 1982:41:109-17.

8 Suleman FE, Velleman MD. Intra-articular rice bodies: Imaging for persistent joint pain. SA Orthopaedic J 2011;104:80.

Copyright 2014 BMJ Publishing Group. All rights reserved. For permission to reuse any of this content visit http://group.bmj.com/group/rights-licensing/permissions.

BMJ Case Report Fellows may re-use this article for personal use and teaching without any further permission.

Become a Fellow of BMJ Case Reports today and you can:

- Submit as many cases as you like

- Enjoy fast sympathetic peer review and rapid publication of accepted articles

- Access all the published articles

- Re-use any of the published material for personal use and teaching without further permission

For information on Institutional Fellowships contact consortiasales@bmjgroup.com

Visit casereports.bmj.com for more articles like this and to become a Fellow 